\title{
Lack of TRPM5-Expressing Microvillous Cells in Mouse Main Olfactory Epithelium Leads to Impaired Odor-Evoked Responses and Olfactory-Guided Behavior in a Challenging Chemical Environment
}

Kayla Lemons, ${ }^{1, *}$ (Diying Fu, ${ }^{1, *}$ Imad Aoudé, ${ }^{1, *}$ Tatsuya Ogura, ${ }^{1, *}$ (D) Julianna Sun, ${ }^{1}$ (DJustin Chang, ${ }^{1}$ Kenechukwu Mbonu, ${ }^{1}$ Ichiro Matsumoto, ${ }^{2}$ Hiroyuki Arakawa, ${ }^{3}$ and ${ }^{\circledR}$ Weihong Lin ${ }^{1}$

DOI:http://dx.doi.org/10.1523/ENEURO.0135-17.2017

${ }^{1}$ Department of Biological Sciences, University of Maryland, Baltimore County, Baltimore, MD, ${ }^{2}$ Monell Chemical Senses Center, Philadelphia, PA, and ${ }^{3}$ Department of Research Administration, School of Medicine, Case Western Reserve University, Cleveland, $\mathrm{OH}$

\section{Visual Abstract}

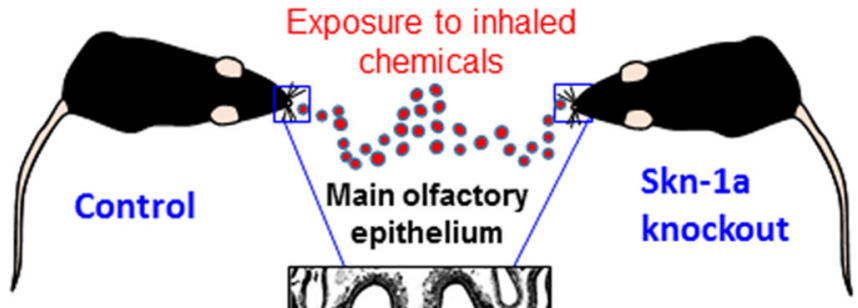

TRPM5expressing microvillous cells
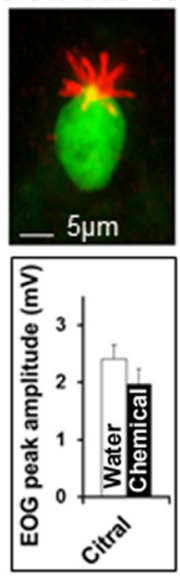

Normal

- food finding

- urine preference - stranger odor preference
No TRPM5-

expressing

microvillous cells

Electro-olfactogram (EOG) recording
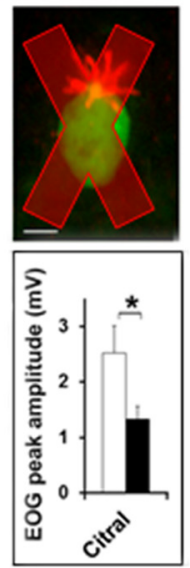

\section{Olfactory behavior assays}

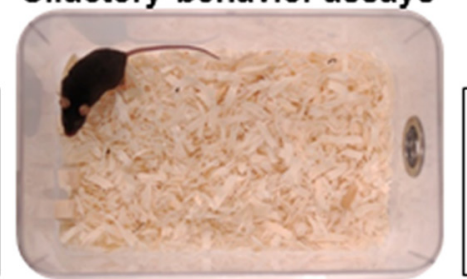

Impaired

- food finding

- urine preference

- stranger odor preference 


\section{Significance Statement}

The main olfactory epithelium (MOE) detects odor molecules and provides sensory inputs for behavioral guidance and modification of the psychological state. Additionally, the MOE protects the brain and respiratory organs by providing an epithelial barrier and biotransforming xenobiotics. The MOE directly faces the respiratory airstream and is vulnerable to damage caused by inhaled odorous irritants, pollutants, and infectious agents. Little is known about the mechanisms that detect xenobiotics and modulate MOE activity for functional maintenance. This study shows that transient receptor potential M5-expressing microvillous cells (TRPM5-MCs) play an important role in maintaining MOE physiological responses to odorants and pheromones in a challenging chemical environment, and subsequently olfactory-guided behaviors. Therefore, these results revealed a novel TRPM5-MC-mediated intercellular regulatory pathway.

The mammalian main olfactory epithelium (MOE) modifies its activities in response to changes in the chemical environment. This process is essential for maintaining the functions of the olfactory system and the upper airway. However, mechanisms involved in this functional maintenance, especially those occurring via paracrine regulatory pathways within the multicellular MOE, are poorly understood. Previously, a population of non-neuronal, transient receptor potential M5-expressing microvillous cells (TRPM5-MCs) was identified in the MOE, and the initial characterization of these cells showed that they are cholinergic and responsive to various xenobiotics including odorants at high concentrations. Here, we investigated the role of TRPM5-MCs in maintaining olfactory function

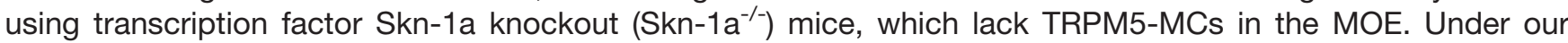
standard housing conditions, Skn-1a ${ }^{-/}$mice do not differ significantly from control mice in odor-evoked electro-olfactogram (EOG) responses and olfactory-guided behaviors, including finding buried food and preference reactions to socially and sexually relevant odors. However, after a 2-wk exposure to high-concentration odor chemicals and chitin powder, Skn- $1 \mathrm{a}^{-/-}$mice exhibited a significant reduction in their odor and pheromoneevoked EOG responses. Consequently, their olfactory-guided behaviors were impaired compared with vehicleexposed Skn-1a ${ }^{-/-}$mice. Conversely, the chemical exposure did not induce significant changes in the EOG responses and olfactory behaviors of control mice. Therefore, our physiological and behavioral results indicate that TRPM5-MCs play a protective role in maintaining the olfactory function of the MOE.

Key words: Olfactory behaviors; olfactory epithelium; olfactory responses; TRPM5; TRPM5-expressing microvillous cells

\section{Introduction}

The mammalian MOE serves three distinct functions. First, it detects thousands of odor molecules and provides sensory inputs that critically influence the brain's psychological state and guide food foraging, habitat selection, mate choice, and social interaction (Buck, 2004; Restrepo et al., 2004; Tirindelli et al., 2009). Second, the MOE

Received April 19, 2017; accepted May 29, 2017; First published June 5, 2017. The authors report no conflict of interests.

Author contributions: KL, ZF, IA, TO, JS, JC, and KM performed experiments. $\mathrm{KL}, \mathrm{ZF}, \mathrm{TO}, \mathrm{JC}$, IM, and HA performed data analysis and participated in drafting the manuscript. WL conceived and supervised the project and drafted most of the manuscript. All authors read, edited and approved the manuscript.

This work was supported by NIH/NIDCD DC012831 to Weihong Lin.

${ }^{*}$ K.L., Z.F., I.A., and T.O. contributed equally to this work.

Acknowledgments: We thank Tim Ford and Wangmei Luo for technical assistance and Kritika Chugh and Abdullah AlMatrouk for proofreading.

Correspondence should be addressed to Weihong Lin, PhD, Department of Biological Sciences, University of Maryland, Baltimore County, Baltimore, MD 21250. E-mail: weihong@umbc.edu.

DOI:http://dx.doi.org/10.1523/ENEURO.0135-17.2017

Copyright (c) 2017 Lemons et al.

This is an open-access article distributed under the terms of the Creative Commons Attribution 4.0 International license, which permits unrestricted use, distribution and reproduction in any medium provided that the original work is properly attributed. serves as an epithelial surface barrier, preventing or minimizing inhaled xenobiotics, such as air pollutants and infectious agents, from entering the brain, where they can create inflammation and neurodegeneration (Prediger et al., 2006; Imamura and Hasegawa-Ishii, 2016). Third, the MOE serves as a primary site for metabolizing and removing xenobiotics in the upper respiratory tract (Chen et al., 1992; Thornton-Manning et al., 1997; Thiebaud et al., 2010). The MOE is susceptible to xenobiotic insults owing to its large surface area and direct contact with inhaled chemicals. However, little is known about mechanisms that detect xenobiotics and subsequently modulate olfactory activity for functional maintenance.

The MOE is made up of olfactory sensory neurons (OSNs), supporting cells (SCs), basal cells, microvillous cells (MCs), and the cells of Bowman's glands and ducts (Morrison and Costanzo, 1992; Farbman, 2000). The MCs display diverse morphology in their apical microvilli and basal processes (Menco and Morrison, 2003), with distinct molecular features. One MC population exhibits short and cone-shaped microvilli. These cells express transient receptor potential channel C6 (TRPC6), respond to odor molecules, and promote MOE adult neurogenesis (Elsaesser and Paysan, 2007; Hegg et al., 2010; Jia et al., 2013). Another population of MCs expresses TRPM5 (Lin 
et al., 2007, 2008b; Hansen and Finger, 2008). These TRPM5-MCs reside superficially throughout the MOE, with their apical microvilli extending into the mucus layer (Lin et al., 2008b; Yamaguchi et al., 2014). They differ from TRPC6-MCs in that TRPM5-MCs exhibit elaborate apical microvilli and generally lack a basal process connecting them to the basal lamina. Also, TRPM5-MCs differ from OSNs in that they do not express neuronal or OSN markers and components of the canonical olfactory transduction pathway (Lin et al., 2008b). Therefore, TRPM5-MCs represent a distinct population in the MOE.

Interestingly, TRPM5-MCs express the cholinergic markers choline acetyltransferase (ChAT) and vesicular acetylcholine transporter (VAChT). Also, TRPM5-MCs respond to various chemical stimuli, such as odorous chemicals, ATP, and bacterial lysate, with increases in intracellular $\mathrm{Ca}^{2+}$ levels (Ogura et al., 2011). These findings led the investigators to hypothesize that TRPM5MCs detect harmful chemicals and subsequently regulate MOE activities for functional maintenance. Currently, TRPM5-expressing chemosensory cells capable of detecting various harmful chemicals have been found in a variety of tissues (Finger et al., 2003; Bezencon et al., 2008; Gulbransen et al., 2008; Lin et al., 2008a; Ogura et al., 2010; Krasteva et al., 2011; Tizzano et al., 2011; Deckmann et al., 2014). However, it is not known how TRPM5-MCs contribute to the overall function of the MOE.

This study sought to determine the physiological and behavioral role of TRPM5-MCs in maintaining proper MOE functions. Knockout of the POU homeobox tran-

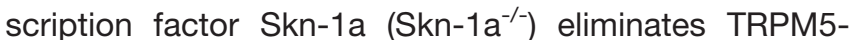
expressing chemosensory cells, including TRPM5-MCs, in the MOE (Matsumoto et al., 2011; Yamaguchi et al., 2014). We first determined whether the lack of TRPM5MCs would affect evoked electro-olfactogram (EOG) responses to odorants and pheromones in mice housed under standard conditions. We then determined whether TRPM5-MCs play a role in MOE maintenance by monitoring EOG responses and performing immunohistological examination after animals were exposed to a mixture of relatively high concentrations of odorants and substances commonly found in the environment and occupational settings. Furthermore, we assayed olfactory ability in guiding behaviors of food searching and preference toward sexually and socially relevant odors. Our data demonstrate that after 2-wk chemical exposure, there was significant impairment in EOG responses and olfactory-guided behaviors in Skn-1 $1 \mathrm{a}^{-/-}$mice but not in control mice, compared with their respective paired vehicleexposed groups. Therefore, our results provide the first evidence that TRPM5-MCs play an important role in maintaining olfactory function and guided behavior.

\section{Materials and Methods}

\section{Animals}

Two- to six-month-old adult male and female C57BL/6 background transgenic and knockout mice were used in this study. For physiologic recordings, mice of both sexes were used. For behavioral experiments, only male mice were used. The TRPM5-GFP transgenic mouse line, in which the promoter of TRPM5 drives the expression of GFP, was originally generated in Robert R. Margolskee's laboratory (Clapp et al., 2006). This mouse line has been used in previous studies of TRPM5-MCs (Lin et al., 2008b; Ogura et al., 2011). In this study, TRPM5-GFP mice were used as controls, and we refer to them as such throughout the article. The Skn-1a $\mathrm{a}^{-/-}$line of mice (RRID: IMSR_RBRC05254) was originally generated by Matsumoto et al. (2011). The lack of TRPM5-MCs in the MOE of these mice has been characterized previously (Yamaguchi et al., 2014). In standard housing conditions, mice were grouphoused (two to five mice per cage) in an open-top cage system in our animal facility. Cages were changed weekly, and water and food were available ad libitum. All animal care and use procedures were conducted in accordance with the National Institutes of Health Guide for the Care and Use of Laboratory Animals (2006) and approved by the Animal Care and Use Committee of the University of Maryland, Baltimore County.

\section{Chemical stimuli and solutions}

Odorants and chemicals for solutions were purchased from Sigma-Aldrich at the highest purity available. Stock solutions of odorants were made and stored in a $-20^{\circ} \mathrm{C}$ freezer. Odorants for EOG recording were freshly made by dilution with vigorous vortexing into Ringer's saline (for EOG recordings; in mM: $145 \mathrm{NaCl}, 5 \mathrm{KCl}, 10$ HEPES, 1 $\mathrm{MgCl}_{2}, 1 \mathrm{CaCl}_{2}, 1 \mathrm{Na}$ pyruvate, and $5 \mathrm{D}$-glucose, $\mathrm{pH}$ 7.2). The adenylyl cyclase activator forskolin was purchased from Calbiochem. Fine chitin powder was purchased from TCl. For urine collection from group-housed adult C57BL/6 female mice, two methods were used. In the first method, individual mice were handheld, and gentle pressure was applied to the lower abdomen to facilitate urination. In the second method, individual mice were placed into a clean cage without bedding, and urine samples were collected after secretion. The urine samples from individual animals were pooled, aliquoted (200 $\mu$ l each), quickly frozen, and stored at $-80^{\circ} \mathrm{C}$. Freshly thawed urine samples were used in experiments. Water samples for the vehicle-exposed control mice and the T-maze odor preference test were obtained from the same tap water source.

\section{Chronic exposure to chemical stimuli}

Mice used for control and exposure conditions were matched for age and sex and group-housed in isolated filter-top cages ( $28 \mathrm{~cm}$ long by $19 \mathrm{~cm}$ wide by $12 \mathrm{~cm}$ high). Animals had free access to food and water throughout the duration of the experiment. The odor mixture for 2-wk exposure included ammonium hydroxide, ethyl acetate, propionic acid, and triethylamine, which were made up individually and mixed before use to a final concentration of $0.019,0.075,0.083$, and $0.013 \mathrm{M}$, respectively. These chemicals were selected largely on the basis of their widespread use in various industrial applications, the possibility of them being inhaled by animals in natural conditions, and their relevance to occupational health/exposure toxicology (Kuwabara et al., 2007). The concentrations of these odors were chosen based on occupational health guidelines for irritation levels (www.cdc.gov/niosh/) and 
the $\mathrm{RD}_{50}$ value, which is the concentration producing a $50 \%$ respiration rate decrease (Kuwabara et al., 2007; van Thriel et al., 2008). The gas phase concentrations for daily exposure, which were derived by the vapor pressure of the mixture at $20-25^{\circ} \mathrm{C}$, were estimated to be $52 \mathrm{ppm}$ for ammonium hydroxide, $180 \mathrm{ppm}$ for ethyl acetate, $4.8 \mathrm{ppm}$ for propionic acid, and $17 \mathrm{ppm}$ for triethylamine, assuming the cage was closed. The intention was to challenge, but not overwhelm, the MOE's ability to maintain its integrity so that we could assess the effects of the exposure on $\mathrm{Skn}-1 \mathrm{a}^{-/-}$mice.

For chemical exposure, a small glass vial (either $1 \mathrm{~cm}$ diameter by $6.5 \mathrm{~cm}$ height or $1.8 \mathrm{~cm}$ diameter by $7 \mathrm{~cm}$ height) containing $4 \mathrm{ml}$ of the chemical mixture with a piece of Kimwipe was placed in the cage. The odor mixture was refilled daily, and mice were exposed either continuously for $14 \mathrm{~d}$ or on weekdays only for at least 14 d total. In addition to the exposure to odorous volatiles, mice in the chemical exposure group were also transferred to a new cage and exposed to chitin powder (250 $\mathrm{mg} /$ cage) for $10 \mathrm{~min}$ daily. Chitin is a characteristic component making up the cell walls of fungi and the exoskeletons of arthropods and insects. Chitin powder was chosen because it can be found abundantly in nature. A small air pump was used to blow air around the cage to prevent the powder from accumulating in the corners or being moistened by urine. Water control groups from both mouse lines were exposed only to vehicle (water).

\section{EOG recordings}

The method was adapted from a previous publication (Lin et al., 2008a). Briefly, mice were euthanized by $\mathrm{CO}_{2}$ inhalation followed by cervical dislocation. To minimize blood in the nasal tissue, exsanguination was performed through an open heart immediately after death. The skinned head was then split along the midline, and the nasal septum was removed to expose the olfactory turbinate. The half head was mounted on a recording chamber using low-melting-point agarose (2\%). Ringer's solution and odorants were delivered through a gravity-fed computer-controlled perfusion system with an approximate flow rate of $0.2 \mathrm{ml} / \mathrm{s}$. Each odorant was presented three times (1-s duration, 1-min interval), and the largest response amplitude among the three repeats was measured for data analysis. The recording electrode was placed on the apical surface of endoturbinate II, and the reference $\mathrm{Ag} / \mathrm{AgCl}$ electrode was placed in bath saline. The glass pipette recording electrode was made using a pipette puller (PP-830, Narishige), and the tip of the pipette was fire polished by a microforge (MF-83, Narishige) and filled with $0.9 \%$ agar made in Ringer's saline with $1 \%$ neutral red. EOG recordings were made at the position of olfactory turbinate II (see Fig. 1A) using a differential amplifier (DP-311, Warner Instruments), a digital I/O and A/D controller (Instrutech ITC-18, Heka Elektronik), a solenoid valve for odor delivery, and a photo-coupler relay controlled by a personal computer with AxoGraph software. The recorded signals were digitized at $500 \mathrm{~Hz}$ and analyzed using AxoGraph software.

\section{Immunohistochemistry}

\section{Tissue preparation}

We followed the immunolabeling procedure used for the initial characterization of TRPM5-MCs (Lin et al., 2008a and 2008b; Ogura et al., 2011). Briefly, mice from standard housing and 2-wk exposure groups were deeply anesthetized with tribromoethanol (Avertin; $250 \mu \mathrm{g} / \mathrm{g}$ body weight), perfusion-fixed with a phosphate-buffered fixative containing $3 \%$ paraformaldehyde, $19 \mathrm{~mm}$ L-lysine monohydrochloride, and $0.23 \%$ sodium $\mathrm{m}$-periodate. The nose was harvested and postfixed for $1.5 \mathrm{~h}$ before being transferred to $0.1 \mathrm{~m}$ PBS with $25 \%$ sucrose overnight for cryoprotection. The nose was then manually deboned following a method described in Dunston et al. (2013), and MOE tissue was embedded. Tissue was then cut into $14-\mu \mathrm{m}$-thick sections using a cryostat (Microm International) and mounted onto Superfrost Plus microscope slides (Thermo Fisher Scientific). The slides were stored in a $-80^{\circ} \mathrm{C}$ freezer until use.

\section{Immunohistochemistry}

MOE sections were rinsed in $0.1 \mathrm{M}$ PBS three times, 10 min each, before incubating in PBS-buffered blocking solution containing $2 \%$ normal donkey serum, $0.3 \%$ Triton $\mathrm{X}-100$, and $1 \%$ bovine serum albumin for $1.5 \mathrm{~h}$. Sections were then immunoreacted for $48-72 \mathrm{~h}$ at $4^{\circ} \mathrm{C}$ with primary antibodies against olfactory marker protein (OMP, 1:1000, Wako 019-22291-WAKO RRID:AB_664696) and growth-associated protein 43 (GAP43, 1:2000, Novus NB300-143 RRID:AB_10001196). After incubation with the primary antibodies, sections were washed and reacted with secondary antibodies conjugated with either Alexa Fluor 555 or 647 (1:400; Invitrogen) for $1 \mathrm{~h}$ at room temperature. Sections were then rinsed and coverslipped with Fluoromount-G containing DAPI, which stains nuclei (Southern Biotech). In control experiments, primary antibodies were omitted, which resulted in negative labeling.

\section{Image acquisition}

Low-magnification images of the MOE were taken using an Olympus BX 41 epifluorescence compound microscope, equipped with a Retiga 4000R camera (QImaging), and acquired with Q-Capture Pro 7 (QImaging). Highmagnification confocal images of immunolabeled sections were taken using an Olympus BX 61 epifluorescence microscope equipped with a spinning disk confocal unit and Slidebook 5.0 software (3i).

\section{Buried food test}

This protocol was adapted from previous publications (Wersinger et al., 2007; Yang and Crawley, 2009). In this test, mice are required to dig to locate a piece of food that is buried under the bedding. To diminish avoidance of novel food during the test, mice were given a small piece of an Oreo cookie for two to three consecutive nights before the experiment. The night before testing, mice were food-deprived overnight for 14-19 $\mathrm{h}$ to increase their interest in food. A small piece of an Oreo cookie ( 70-110 mg) was buried under a layer of bedding 5-6 $\mathrm{cm}$ thick in a $16 \times 15-\mathrm{cm}$ search space within a standard mouse cage (see Fig. 4A). Mice were placed in the cage 
A

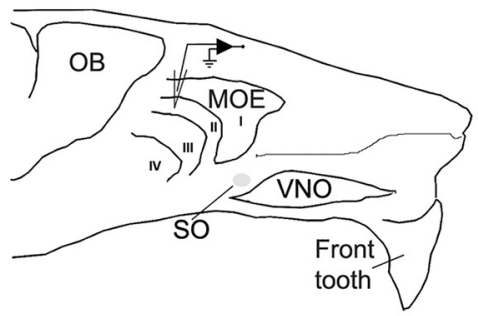

D
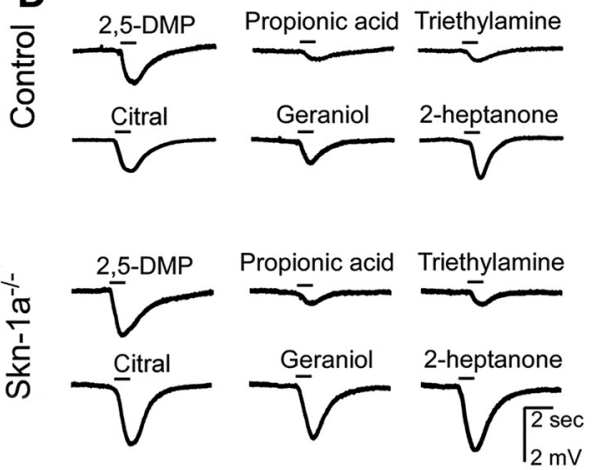

B
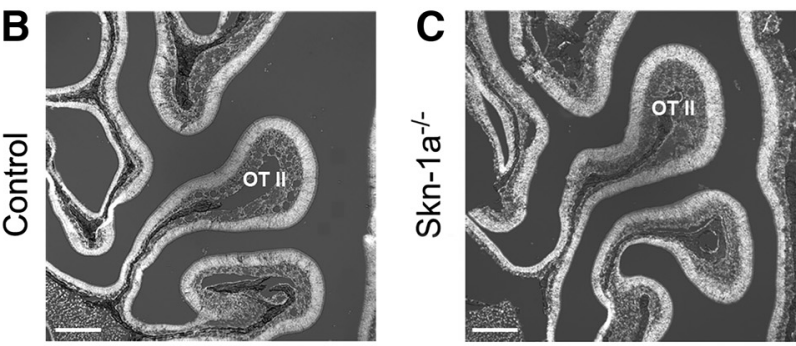

E

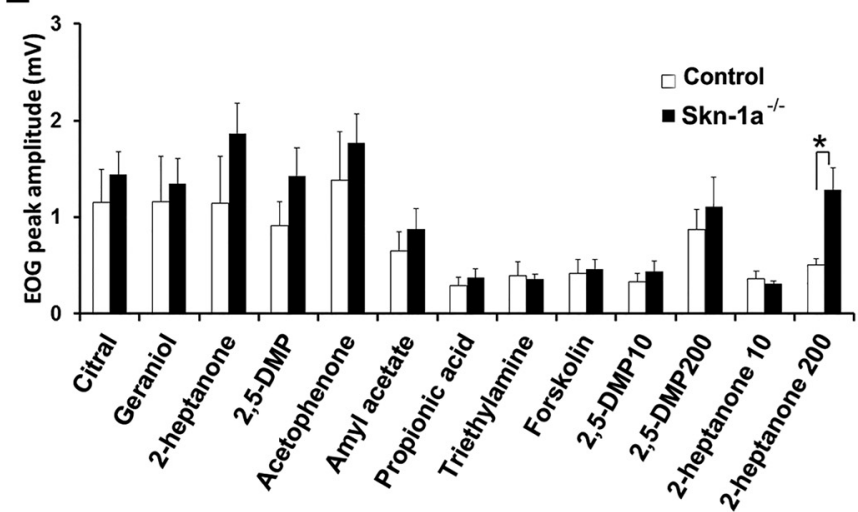

Figure 1. Odorants and pheromones evoke comparable EOG responses in control and Skn-1a ${ }^{-/-}$mice housed under our standard conditions. $\boldsymbol{A}$, Schematic drawing of a mouse heminose, showing the region where the EOG responses were recorded in the olfactory turbinate II. MOE, main olfactory epithelium; OB, olfactory bulb; VNO, vomeronasal organ; SO, septal organ. $\boldsymbol{B}$, $\boldsymbol{C}$, Representative images of MOE from control and Skn-1 $\mathrm{a}^{-/-}$mice, respectively, approximately corresponding to the region of EOG recording. The sections were stained with DAPI and imaged with additional weak transmitted light to review the morphology of the MOE in the area of olfactory turbinate II (OT II). Scale bar: $100 \mu \mathrm{m}$. $\boldsymbol{D}$, Representative EOG traces. $\boldsymbol{E}$, Average peak EOG responses to various stimuli $\left(n=6\right.$, mean \pm SEM). Chemical stimuli were applied in exactly the same sequence for EOG recordings for both control and Skn-1a ${ }^{-/-}$ mice. The EOG responses to various odorants and pheromones at $100 \mu \mathrm{m}$ were recorded first, followed by responses to the adenylyl cyclase activator forskolin $(1 \mu \mathrm{M})$. Finally, the EOG responses to 2,5-dimethylpyrazine (2,5-DMP) and 2-heptanone (10 and $200 \mu \mathrm{M})$ were recorded. There was no significant difference in EOG amplitude in response to the same odorant between Skn-1 $\mathrm{a}^{-/-}$and control mice, except 2-heptanone at $200 \mu \mathrm{M}$ ( $*, p<0.05, t$ test, $n=6$, mean \pm SEM).

and allowed to freely explore the cage for 5 min (maximum cutoff). Mouse behavior was videorecorded from the side view to score the latency to locate the buried food. The mouse was considered to have successfully located the buried food when either its paws or snout reached within $1 \mathrm{~cm}$ of the cookie piece. Any animals that took longer than the cutoff time were excluded from further data analysis. One of a total of 13 mice from the group of control mice exposed to chemicals and two of a total of 14 mice from the water-exposed $\mathrm{Skn}-1 \mathrm{a}^{-/-}$mice group were excluded for this reason. After the test, the mouse was returned to its home cage and supplied with food and water.

\section{T-maze odor choice test}

A T-maze apparatus was used to assess the ability of male mice to detect socially and sexually relevant odors (Kavaliers et al., 1994). The transparent polycarbonate plastic T-maze apparatus consists of two arms $(40 \mathrm{~cm}$ length and $10 \mathrm{~cm}$ width) with a short start arm $(25 \mathrm{~cm}$ length; see Fig. $5 A$ ). The start arm has a movable gate to allow a mouse to access either the left or right arm, which avoids counting the time the mouse spends in the unclassified area between the two testing arms. The mice explore the T-maze based on olfactory cues presented only at the end of the arms. To eliminate visual cues, the experiment was performed in the dark, and mouse behavior was videorecorded under infrared lighting (Foscam F18918W). For the experiment, a single mouse was placed in the start arm while the gate was closed, which prevented it from entering the arms. After a 5-min acclimation, the gate was opened and the mouse was allowed to freely explore the maze for $10 \mathrm{~min}$. Water and (female) urine samples $(200 \mu \mathrm{l})$ were placed at the very end of the left and right arms randomly (1 $\mathrm{cm}$ from the wall) in a $35-\mathrm{mm}$ Petri dish. At the end of the experiment, the mouse was returned to its home cage, and the whole apparatus was manually cleaned with $15 \%$ ethanol and dried with a fan to blow out any residual odor. The locations of the odor samples were counterbalanced between mice to eliminate possible location preference, and new samples were used for every trial. Mouse movements between the choice arms were evaluated in terms of approach behaviors when orienting toward the odor sources. When a mouse spent time in proximity to either Petri dish, it was considered to be sniffing the samples. Proximity was defined as the mouse's snout coming within $1 \mathrm{~cm}$ of a Petri dish. JWatcher software (UCLA and Macquarie University) was used to quantify these parameters. The urine preference ratio was calculated by divid- 
ing the percentage of time spent in sniffing the urine dish by the total time spent sniffing both water and urine dishes.

\section{Block test to differentiate body odors}

A modified version of the block test was conducted to assess olfactory-guided preference behavior based on the detection and discrimination of social odors (Tillerson et al., 2006; Fleming et al., 2008; Lehmkuhl et al., 2014). Naive male mice were individually housed in clean cages overnight ( $\sim 18 \mathrm{~h}$ ) with four wood blocks [labeled A-D; (15 $\mathrm{mm})^{3}$ ] placed inside the cage to obtain the individual mouse's body odor. The following day, $1 \mathrm{~h}$ before beginning the experiment, these self-scented blocks were removed from the animals' cages and kept in Ziploc bags with bedding for the duration of the experiment. The test consisted of three 2-min trials, separated by a $\sim 15-$ to 20-min intertrial interval. Individual mice naive to the assay were acclimated in their individual standard shoebox cages for $1 \mathrm{~h}$ before testing. The same cages were used for the test. At the beginning of each trial, the four blocks with the same scent cues (self body odor) were placed into the test cage with as little disturbance as possible (see Fig. 6A for setup). Blocks were placed in a random order with the letters facing the camera. In the first two trials, the self-scented blocks labeled A-D were presented. In the third trial, block $D$ was replaced with a new block (E) with odor of a stranger male mouse. During trials, the mouse explored the blocks freely, and all tests were videorecorded for later analysis. An experimenter who was blind to genotype used JWatcher to determine the duration investigating the blocks and the number of approaches to each block. Approaches were defined as any movement that brought the mouse's nose into close physical proximity (less than $1 \mathrm{~cm}$ ) with a block. The mouse was considered to be sniffing when the mouse's snout came into the close proximity with the blocks. Inactive mice that fixated on one block or failed to approach the blocks at least three times during the 2-min trial were excluded from data analysis.

\section{Statistical analysis}

All data are presented as mean \pm SEM. Student's $t$ test was used to compare results between the two experimental groups (chemical-exposed versus water-exposed). If the $F$ test was significant and homogeneity of variance was not assumed, Welch's $t$ test was used instead of Student's $t$ test. For the approach data from the block test, a comparison of the number of approaches for each block was made by a one-way ANOVA. Bonferroni corrections were performed for the post hoc comparisons as needed. For all tests, $p<0.05$ was considered to be statistically different. During our study, a report about the relatively higher metabolism of Skn- $1 \mathrm{a}^{-/-}$mice was published (Ushiama et al., 2016). For this reason, we compared data only from animals that were paired, i.e., vehicle- versus chemical-exposed animals within the same mouse line.

\section{Results}

\section{Skn-1a ${ }^{-/-}$mice do not show altered olfactory responses when housed under standard conditions}

We first examined whether odor-evoked EOG responses are altered in Skn-1a ${ }^{-/-}$mice lacking TRPM5MCs in the MOE, since physiological characterization of the impact of Skn-1a knockout in the olfactory system has not previously been performed. For olfactory stimuli, we used citral, geraniol, acetophenone, and amyl acetate as common volatile odorants. We also included propionic acid and triethylamine, which were present in our odor mixture for the 2-wk exposure. Propionic acid was selected because it can be produced by bacteria commonly found in nasal mucosa (Boase et al., 2013), and TRPM5MCs respond to bacterial lysate (Ogura et al., 2011). Triethylamine was chosen for its widespread use in chemical synthesis. Additionally, synthetic urinary pheromones 2-heptanone and 2,5-dimethylpyrazine (2,5-DMP) and the adenylyl cyclase activator forskolin were included as MOE stimuli. EOGs were recorded from the olfactory turbinate II as indicated (Fig. 1A). Histologic examination of MOE sections obtained from the same region showed similar morphology between control TRPM5-GFP and Skn-1a ${ }^{-/-}$ mice (Fig. $1 B$ and $C$, respectively). We found that control and $\mathrm{Skn}-1 \mathrm{a}^{-/-}$mice housed under standard conditions responded to all volatile stimuli $(100 \mu \mathrm{M})$ and forskolin (1 $\mu \mathrm{M}$ ) tested during EOG recordings (Fig. $1 D$ : representative EOG traces from control and Skn-1a ${ }^{-/-}$mice). Responses obtained from Skn-1 $1 \mathrm{a}^{-/-}$mice trended slightly higher for most of the stimuli but were not significantly different from the EOG responses of control mice (Fig. 1E; $t(9)=0.217-1.387, p=0.1-0.3, n=5$ and 6 , control and Skn-1a ${ }^{-/-}$mice), except for 2-heptanone (200 $\mu \mathrm{M} ; t(7)=$ $3.669, p=0.004$; Fig. $1 E$ : plot of average response amplitude to individual stimuli). Forskolin did not cause any difference in EOG between control and Skn-1a $\mathrm{a}^{-/-}$mice. We also observed no apparent differences in the response kinetics, such as the rates of activation and recovery between control and Skn-1a ${ }^{-/-}$mice (data not shown). Therefore, the lack of TRPM5-MCs in the MOE of Skn-1a ${ }^{-/-}$mice does not have a significant impact on evoked olfactory responses to select odorants and pheromones under standard housing conditions.

\section{Reduced odor-evoked EOG responses in Skn-1a ${ }^{-/-}$ mice after a 2-wk chemical exposure}

Previously, TRPM5-MCs were found to be responsive to odorous stimuli at relatively high concentrations and capable of releasing acetylcholine (ACh), which modulates intracellular $\mathrm{Ca}^{2+}$ levels in OSNs and supporting cells (Ogura et al., 2011). These findings have led to a hypothesis that TRPM5-MCs are involved in the maintenance of MOE function in challenging chemical environments. To test this, we performed EOG recordings in control and Skn-1 $\mathrm{a}^{-/-}$mice after they had been exposed to a mixture of chemicals and chitin for $2 \mathrm{wks}$. We found that EOG responses in chemical-exposed control TRPM5GFP mice trended lower compared with the waterexposed mice. However, the reduction was not significant for odorants citral and geraniol and pheromones 
2-heptanone and 2,5-DMP (Fig. $2 A, t(29)=1.209-1.602$, $p=0.1-0.2, n=15$ and 16 , water and chemical-exposed, respectively), as well as for the two chemical exposure compounds propionic acid and triethylamine (Fig. 2A; $t(29)=0.451-0.917, p=0.1-0.2, n=15$ and 16, water and chemical-exposed, respectively). In contrast, in chemical-exposed Skn-1a ${ }^{-/}$mice, the average EOG amplitudes were significantly reduced for most of the stimuli, including odorants, pheromones, and chemicals in the exposure mixture, compared with the $\mathrm{Skn}-1 \mathrm{a}^{-/-}$mice of the water-exposed group (Fig. $2 B ; t(31)=1.852-2.351, p$ $=0.019-0.041, n=15$ and 18 , water and chemicalexposed, respectively). Therefore, these EOG results obtained after chemical exposure indicate an important role of TRPM5-MCs in maintaining the olfactory responses of the MOE.

We also investigated the impact of chemical exposure on dose-dependent responses to 2-heptanone and 2,5DMP $(10,100$, and $200 \mu \mathrm{M})$, since these volatile urinary pheromones were most likely present in their housing environment. Reduced EOG responses were found at all three concentrations in the chemical-exposed groups, with a larger reduction in Skn-1a ${ }^{-1-}$ mice, as expected. When the responses were normalized to the peak response values obtained at $200 \mu \mathrm{M}$ from the same animals, we found that the dose-response curves for these two pheromones were similar between the chemical- and vehicle-exposed control mice (Fig. $2 C, D ; t(\mathrm{df})=0.173-$ $1.423, p=0.173-1.425$ for both 10 and $100 \mu \mathrm{M}, n=4-6$ ). In striking contrast, Skn-1a $\mathrm{a}^{-/-}$mice in the chemical exposure group showed significantly smaller responses to these stimuli at $10 \mu \mathrm{M}$ concentration compared with those obtained from the water-exposed Skn-1 $\mathrm{a}^{-/-}$mice (Fig. 2E, $F ; t(d f)=3.180$ and 3.315 for 2-heptanone and 2,5-DMP, respectively, $p=0.006$ and $0.005, n=5-6)$, indicating impaired sensitivity to urinary pheromones in Skn-1a ${ }^{-/-}$ mice after chemical exposure. Together, these results suggest that TRPM5-MCs are important for the MOE to maintain its functional integrity.

\section{Two-week chemical exposure does not significantly alter the morphology of the posterior MOE}

The deficit in evoked odor responses in chemicalexposed Skn-1a ${ }^{-/-}$mice could result from impaired functional modification or damage to the MOE tissue. The MOE thickness varies substantially depending on regions under normal conditions. We performed immunohistochemical examination of MOE sections obtained from the approximate region where the EOG responses were recorded using antibodies against GAP43 and OMP, which label immature and mature OSNs, respectively. The sections were also stained with DAPI to view the nuclei. We found that the MOE of turbinate II from mice of all four groups exhibited similar morphology, with a smooth surface and no apparent swelling of DAPI-labeled nuclei, indicating that the 2-wk chemical exposure caused minimal or no tissue damage in this region for either control TRPM5-GFP or Skn-1a ${ }^{-/-}$mice (Fig. 3A, F, K, P; confocal images of DAPI staining). Similar labeling for GAP43 and OMP was also seen in these regions (Fig. $3 B, G, L, Q$ for
GAP43; Fig. 3C, $H, M, R$ for OMP). Furthermore, there was no drastic change in the number of TRPM5-MCs (GFP positive, Fig. $3 D$, I from water- and chemical-exposed, control TRPM5-GFP mice, respectively; Fig. 3E, J, O, T: overlay of GAP 43, OMP, and GFP). Therefore, impairment in functional modification rather than tissue damage most likely underlies the significant reduction in the EOG responses observed in chemical-exposed Skn-1a ${ }^{-/-}$mice.

\section{Skn-1a ${ }^{-/-}$mice exhibit compromised olfactory ability to locate buried food after a 2-wk chemical exposure}

We next investigated whether the reduction in odorevoked EOG responses in the chemical-exposed Skn$1 \mathrm{a}^{-/-}$mice leads to deficits in olfactory-guided behaviors. Fig. $4 A$ shows the setup for assessing the animals' general olfactory ability to locate buried food. To avoid learning-related complications, we performed this assay using only naive mice that had never been previously tested for finding buried cookies. We first assessed whether Skn-1a ${ }^{-/-}$and control mice, which were housed under our standard conditions without the chemical exposure, differed in the time required to locate the buried cookie. We found there was no difference in their performance (Fig. $4 B ; t(\mathrm{df})=25, p=0.175, n=13$ and 14 , respectively).

We performed the same test on control and Skn-1a $\mathrm{a}^{-/-}$ mice after 2-wk water or chemical exposure. Chemicalexposed control mice showed no difference in performance compared with water-exposed mice (Fig. $4 C$; $t(19)$ $=0.903, p=0.189, n=9$ and 12, water- and chemicalexposed, respectively), indicating that chemical exposure did not have an adverse impact on olfactory-guided food searching behavior in control mice. In contrast, chemicalexposed Skn-1a ${ }^{-/-}$mice took significantly longer to locate a buried cookie than water-exposed Skn-1 $\mathrm{a}^{-/}$controls (Fig. $4 C, t(19.9)=2.424, p=0.013, n=9$ and 14 , waterand chemical-exposed, respectively). These data indicate that the olfactory ability of guiding food-finding was impaired in Skn-1a ${ }^{-/-}$mice, but not in control mice after chemical exposure.

\section{Olfactory preference toward urine of the opposite

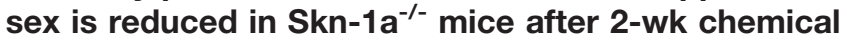 exposure}

In addition to sensing common airborne odorants, the MOE and its associated main olfactory system play an important role in detecting and discriminating semiochemicals and providing guidance for social and sexual behaviors (Keverne, 2004; Mandiyan et al., 2005; Lin et al., 2007; Fraser and Shah, 2014; Lopez et al., 2014). Semiochemicals or social/sexual odors present in body secretions, such as urine, contain rich information about the genetic background as well as social and sexual status of the animals (Boehm and Zufall, 2006; Brennan and Zufall, 2006; Restrepo et al., 2006; Peretto and Paredes, 2014). Generally, male mice are keen to investigate female urine over water (Achiraman and Archunan, 2002). We investigated whether chemical exposure would compromise the detection of urine from the opposite sex (female) using a T-maze choice test (Fig. 5A). Individual male mice in these 
A
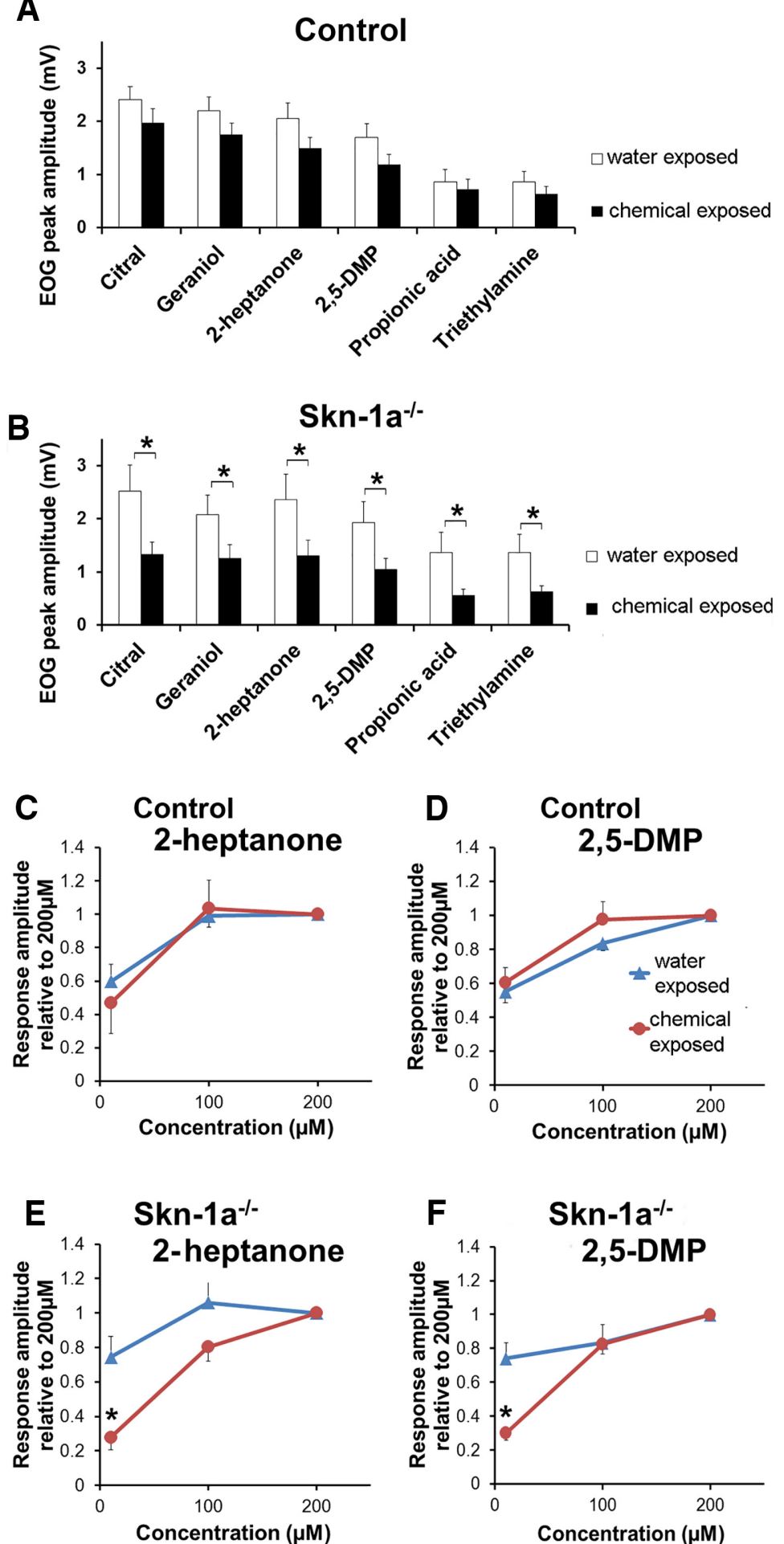

Figure 2. EOG responses in chemical-exposed $\mathrm{Skn}-1 \mathrm{a}^{-/-}$mice are significantly reduced. $\boldsymbol{A}$, Average peak EOG responses to odorants and pheromones at $100 \mu \mathrm{m}$ in control mice. There was no significant difference in the response amplitude to the same stimuli between water- and chemical-exposed groups ( $p>0.05$, $t$ test, $n=15$ and 16, respectively). $\boldsymbol{B}$, Average peak EOG responses to odorants at $100 \mu \mathrm{m}$ in Skn-1a ${ }^{-/-}$mice. The EOG responses obtained from the chemical-exposed group were significantly smaller than those from the water-exposed group ( $*, p<0.05 t$ test, $n=15$ and 18 , respectively). $\boldsymbol{C}-\boldsymbol{F}$, Normalized EOG responses to 2 -heptanone or $2,5-\mathrm{DMP}$ at various concentrations $(10,100$, and $200 \mu \mathrm{M})$, which are presented relative to the values of EOG responses at $200 \mu \mathrm{M}$ of the same animals. There was no significant difference in the dose-dependent responses between the water- and chemical-exposed groups in control mice $(p>0.05, n=4-6)$. In Skn-19 ${ }^{-/-}$mice, normalized responses at $10 \mu \mathrm{M}$ in chemical-exposed group are significantly smaller than responses of the vehicle group ( $*, p<0.05, t$ test, $n=5-6)$. 

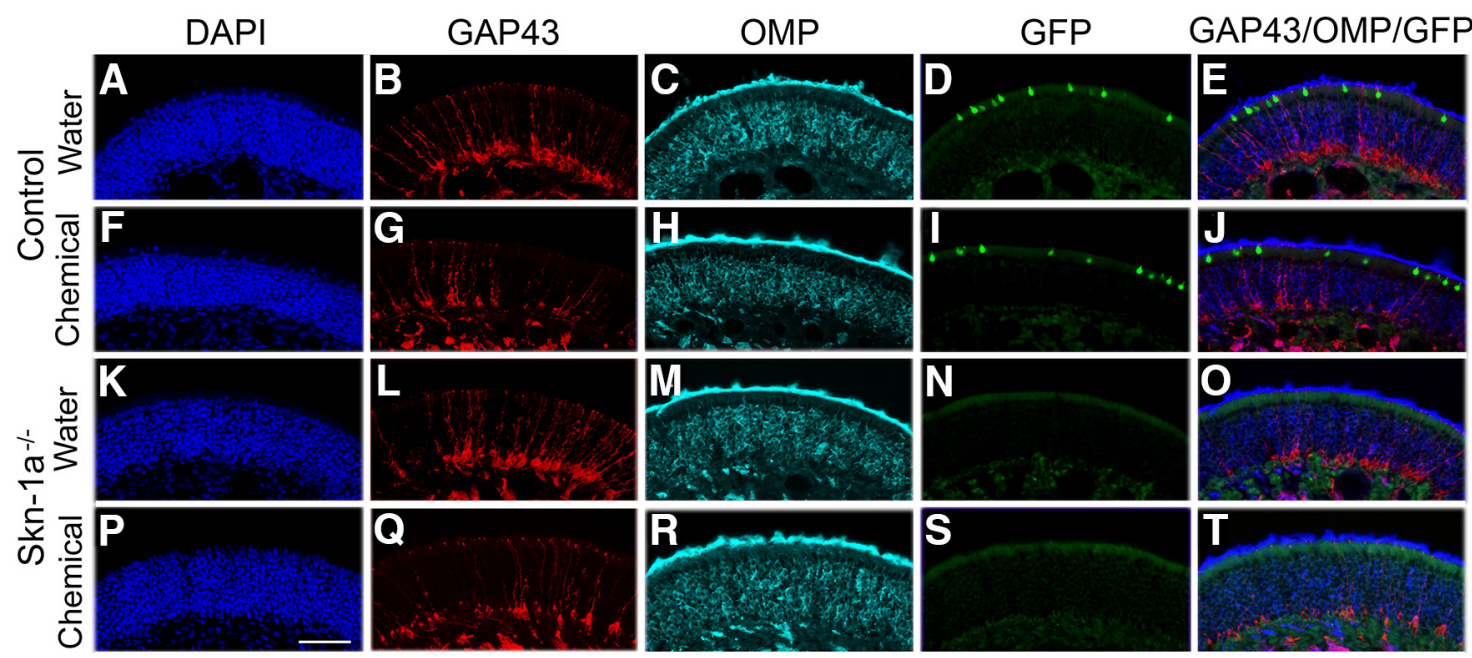

Figure 3. Immunohistochemical examination of the posterior MOE in control and Skn-1a ${ }^{-/-}$mice after 2-wk exposure. Posterior MOE sections at approximately the same region where EOG was recorded were obtained from control and Skn-1 $\mathrm{a}^{-/-}$mice exposed to either water or chemicals for 2 wks. The sections were immunoreacted with antibodies against GAP43 and OMP and stained with DAPI.

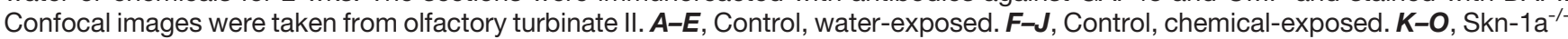
mouse, water-exposed. $\boldsymbol{P}-\boldsymbol{T}$, Skn-1a ${ }^{-/-}$mouse, chemical-exposed. DAPI staining (blue; $\boldsymbol{A}, \boldsymbol{F}, \boldsymbol{K}, \boldsymbol{P}$ ); GAP43 immunoreactivity (red; $\boldsymbol{B}$, $\boldsymbol{G}, \boldsymbol{L}, \boldsymbol{Q}$ ); OMP immunoreactivity (cyan; $\boldsymbol{C}, \boldsymbol{H}, \boldsymbol{M}, \boldsymbol{R}$ ); GFP-positive TRPM5-MCs (green; $\boldsymbol{D}$ and $\boldsymbol{I}$ only, control mice); overlay of GAP 43, OMP, and GFP $(\boldsymbol{E}, \boldsymbol{J}, \boldsymbol{O}, \boldsymbol{T})$. Similar morphology and marker expression were found in four groups of mice, indicating there was no obvious tissue damage in both control and $\mathrm{Skn}-1 \mathrm{a}^{-/-}$mice after chemical exposure in the posterior MOE regions where EOG recordings were performed. Scale bar: $50 \mu \mathrm{m}$.

groups were tested before and after the 2-wk exposure. Both control and Skn-1a ${ }^{-/-}$mice were clearly capable of discriminating between urine and water in the preexposure trial and preferred female urine, as shown by the higher duration of time spent sniffing the urine sample than water (Fig. 5B, control mice, pre-water exposure; $t(4)$ $=4.386, p=0.006, n=5$; Fig. $5 C$, control mice, prechemical exposure $t(7)=3.614, p=0.004, n=8$; Fig. $5 D$, Skn-1a ${ }^{-1}$ mice, pre-water exposure, $t(5)=4.115, p=$ $0.005, n=6$; Fig. $5 E$, Skn-1a ${ }^{-/-}$mice, pre-chemical exposure $t(6)=2.574, p=0.021, n=7$ ). After chemical exposure, control mice maintained the preference for urine over water (Fig. 5B, post-water exposure; $t(5)=$ $3.307 p=0.015, n=5$; Fig. $5 C$, post-chemical exposure $t(7)=2.714, p=0.015, n=8)$. However, olfactory detection and discrimination ability were impaired in chemical-exposed Skn-1a ${ }^{-/}$mice, as these mice no longer significantly preferred urine over water compared with the water-exposed Skn-1a ${ }^{-/-}$mice (Fig. 5D, post-water exposure, $t(5)=5.646, p=0.001, n=6$; Fig. $5 E$, postchemical exposure $t(6)=0.504, p=0.316, n=7$ ).

A further analysis of urine preference ratio confirmed the effect of chemical exposure. In the pre-exposure test, there were no significant differences in urine preference ratio between intended water- and chemical-exposed groups of either control mice (Fig. $5 F, t(11)=1.281 p=$ $0.113, n=5$ and 8) or Skn-1a ${ }^{-/-}$mice (Fig. 5G, $t(11)=$ $0.850, p=0.207, n=6$ and 7 ). After exposure, chemicalexposed control mice did not show a significant reduction in the urine preference ratio compared with the waterexposed control mice (Fig. $5 F, t(11)=1.242, p=0.120, n$ $=8$ and 5). However, chemical-exposed Skn-1 $\mathrm{a}^{-/-}$mice showed a significant reduction in the urine preference ratio compared with the water-exposed $\mathrm{Skn}-1 \mathrm{a}^{-/-}$mice
(Fig. 5G, $t(11)=2.136, p=0.028, n=7$ and 6). These results demonstrated that unlike control mice, Skn-1a ${ }^{-/-}$ mice were not able to maintain their olfactory ability of detecting odors from the opposite sex to guide their behavioral reaction after chemical exposure.

\section{Impaired detection of novel social odors in Skn-1a ${ }^{-/-}$ Mice after a 2-wk chemical exposure}

Finally, we examined the olfactory ability of Skn-1a ${ }^{-/-}$ and control mice to detect and discriminate social odors by assessing their behavior toward the body odor of a stranger mouse versus their own body odor, using a modified version of the block test described previously (Fleming et al., 2008; Lehmkuhl et al., 2014; Tillerson et al., 2006). During the first two trials of this assay, when individual mice were presented with four wooden blocks scented with their own body odors (Fig. 6A), both control and Skn-1 $\mathrm{a}^{-/-}$mice exposed to either water or chemicals were interested in blocks scented by their own odors and sniffed the individual blocks readily (Fig. 6B, C: total sniff durations for trial 1 and 2 of control and Skn- $1 \mathrm{a}^{-/-}$mice, respectively). In the third trial, when a block with the mouse's own scent was replaced with a block scented with a stranger's odor, both control and Skn- $1 \mathrm{a}^{-/-}$mice exposed to either water or chemicals showed a strong interest in the block with the stranger's odor, as evidenced by significant increases in the total sniffing duration (including stranger scent) in trial 3 compared with trial 2 (own scent only; control, water, $t(13)=1.889, p=$ $0.041, n=7$ and 8; control, chemical, $t(13)=1.799, p=$ 0.048, $n=7$ and 8; Skn-1a ${ }^{-/}$, water, $t(16)=1.855$, $p=0.041, n=9$; Skn-1a ${ }^{-/}$, chemical, $t(17)=2.895, p=$ $0.005, n=9$ and 10). The increased duration of sniffing the blocks indicates that these mice were capable of 
A
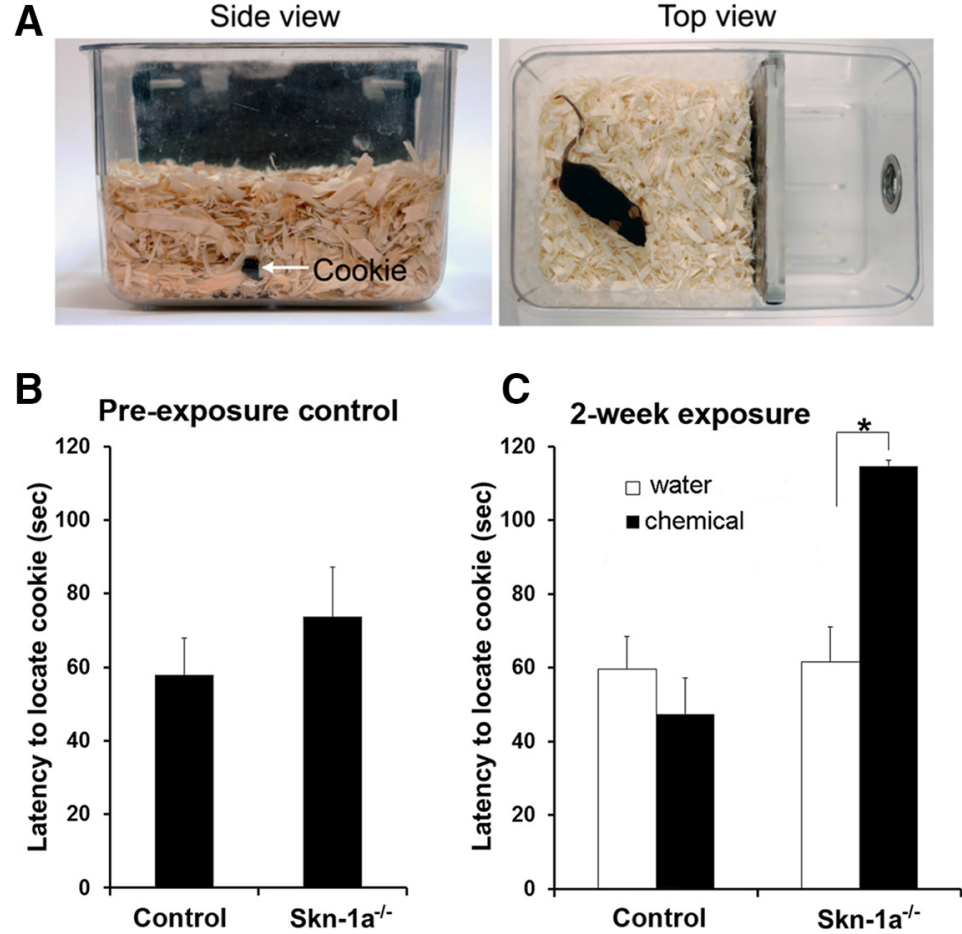

Figure. 4. Impaired olfactory ability to locate buried food in Skn-1a ${ }^{-/-}$mice after chemical exposure. A, Photographs of the experimental setting for the buried food test. Left panel: side view, showing 5- to 6-cm wood chip bedding over a buried cookie piece (indicated by an arrow). Right panel: top view before a mouse began to search for the piece of cookie. B, $\boldsymbol{C}$, Plot of the average time (latency) required for mice to locate the buried cookie. The latency was not significantly different between control and Skn-1 $\mathrm{a}^{-/-}$mice housed under our standard conditions $\left(\boldsymbol{B} ; n=14\right.$ and 13 , WT and Skn-12 ${ }^{-/-}$, respectively). After chemical exposure, Skn-1a ${ }^{-/-}$mice took a significantly longer time to locate the buried cookie compared with the water-exposed group ( $* p<0.05, t$ test, $n=14$ and 9 , respectively). There was no difference between the water- and chemical-exposed groups of control mice $(\boldsymbol{C} ; n=9$ and 12 , respectively).

detecting and discriminating social odors and were motivated to investigate semiochemicals embedded in the scented blocks.

Both the MOE and vomeronasal organ (VNO) sense social odors. However, the MOE is often required for detecting the volatile components in social odor blends and guiding the animal to the stimulus source (Keller et al., 2006; Slotnick et al., 2010). Given the sequential process of olfactory behavior, we closely examined the number of approaching/sniffing events. During a typical sniffing event, mice often stretch their bodies toward the stimulus to approach and assess it and then quickly retreat/draw back (Blanchard et al., 2011). We counted the number of assessment events (approaching) to evaluate how control and Skn-1 $\mathrm{a}^{-/-}$mice differentiated the stranger-scented block from self-scented blocks. Fig. $6 D$ depicts the mean number of approaches to each block in control and Skn$1 \mathrm{a}^{-/-}$mice that were exposed to water or chemicals in trial 3. One-way ANOVA on the number of approaches to the blocks (A, B, and C blocks, own odor; E block, stranger odor) revealed an asymmetry profile of the proportion of block approaches in both control and Skn-1a ${ }^{-1-}$ mice. Control mice exposed to either water or chemicals exhibited a greater number of approaches to the strangerscented block compared with self-scented blocks (control, water-exposed, $F(3,24)=12.10, p<0.0001, n=7$; control, chemical-exposed $F(3,28)=15.97, p<0.0001, n$
$=8$ ). Similarly, Skn-1a ${ }^{-/-}$mice exposed to water displayed more approaches to the stranger scent block compared with other self-scented blocks (water-exposed, $F(3,32)=$ 12.98, $p<0.0001, n=9$ ), whereas Skn-1 $\mathrm{a}^{-/-}$mice that were exposed to chemicals failed to show a significant increase in the number of approaches to the strangerscented block compared with self-scented blocks (chemical-exposed, $F(3,36)=3.215, p=0.0341, n=10$, Bonferroni corrections vs. the stranger-scented block Ps $>0.05$ ). These results indicate that control mice were able to maintain their olfactory ability of discriminating social odors (self vs. stranger), whereas this ability was impaired in $\mathrm{Skn}-1 \mathrm{a}^{-/-}$mice after chemical exposure.

We calculated the ratio of the number of approaches to the stranger-scented block over the total number of times approaching all blocks in control and Skn- $1 \mathrm{a}^{-/-}$mice exposed to water or chemicals (Fig. 6E). Control mice displayed a similarly high ratio of approaches to the stranger block regardless of exposure condition $(t(13)=0.502, p=$ $0.312, n=7$ and 8$)$. In contrast, Skn-1 $\mathrm{a}^{-/-}$mice that were exposed to chemicals showed a significant decrease in approach ratio compared with those that were exposed to water $(t(17)=1.870, p=0.039, n=10$ and 9). Altogether, our analysis of sniffing behavior in the block test indicates the significant impairment of social odor discrimination in Skn- $1 a^{-/-}$mice after chemical exposure. 
A

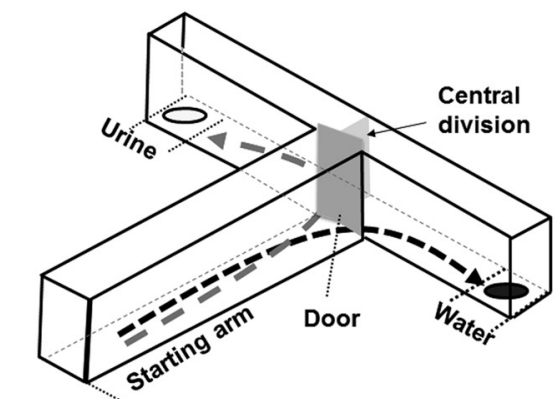

Door Open

Acclimation : Sniff behavior test

$0 \mathrm{~min} \quad 5 \mathrm{~min}$

15 min
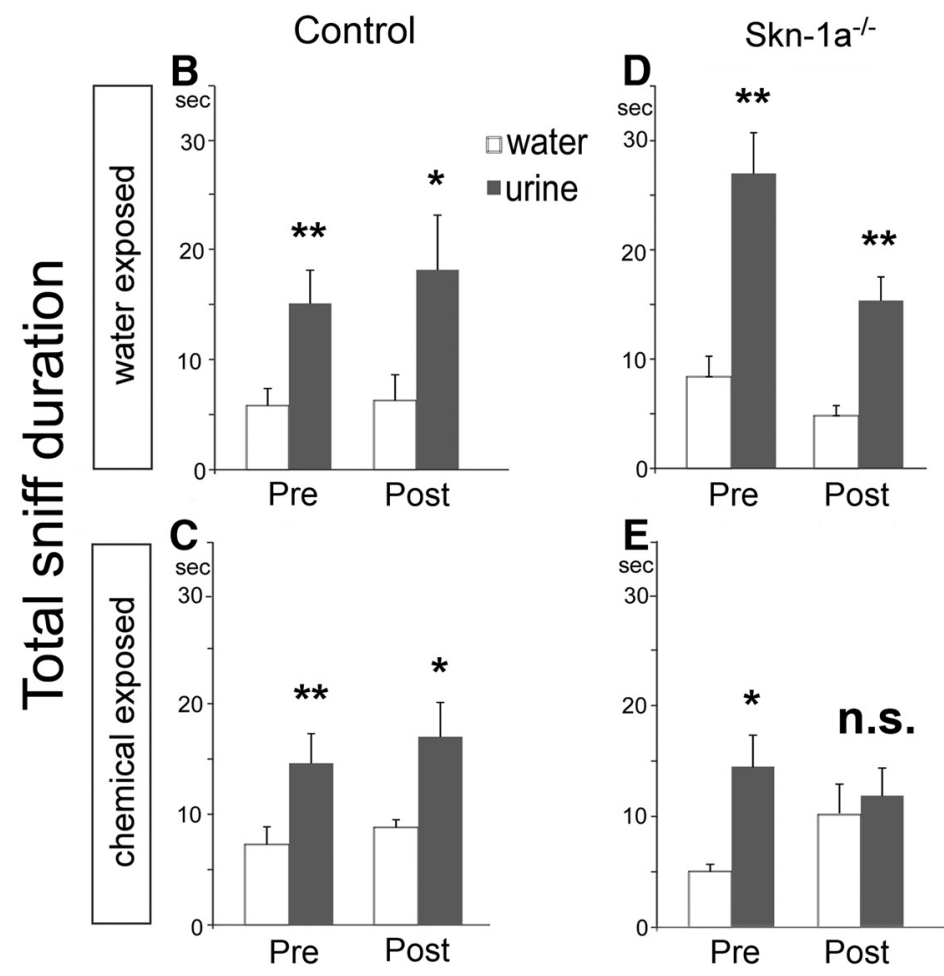

\section{F Control}

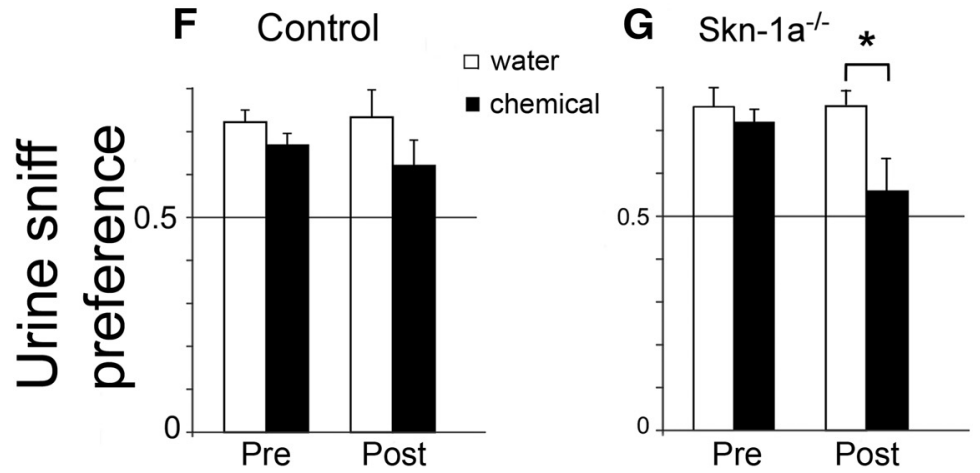

Figure 5. Olfactory preference toward urine of the opposite sex is compromised in chemical-exposed Skn-1a ${ }^{-/-}$mice. $\boldsymbol{A}$, Schematic drawing of the T-maze apparatus used to test olfactory preference for urine. A single mouse was placed in the starting arm of the T-maze for a 5-min acclimation period before the gate was opened, which allowed the mouse to enter either arm. B-E, Plots of total sniff duration. Both control and Skn-1 $\mathrm{a}^{-/-}$male mice displayed a strong preference for the female urine samples before exposure $(*$, $p<0.05$, **, $p<0.01$, paired $t$ test, $n=5-8$ ). Control mice retained their strong preference for urine samples after exposure to either 
continued

water or chemicals (*, $p<0.05$, **, $p<0.01$, paired $t$ test, $n=5-8)$. In contrast, only the water-exposed Skn-1a ${ }^{-/-}$mice maintained the strong preference $(* *, p<0.01$, paired $t$ test, $n=6)$. Chemical-exposed Skn-1a ${ }^{-/-}$mice no longer significantly preferred urine over water ( $p=0.316$, paired $t$ test, $n=7)$. $\boldsymbol{F}, \mathbf{G}$, Plots of sniff preference (ratio of urine sniff duration over total sniff duration). No significant difference was found in the control mice pre- and post-exposure ( $p=0.113$ and 0.120 , respectively, $t$ test), or the pre-exposure Skn-1 $\mathrm{a}^{-/-}$mice group ( $p=0.207, t$ test). However, a significant reduction was found in Skn-1a ${ }^{-/-}$mice of chemical-exposed group compared with the water-exposed group (*, $p<0.05, t$ test).

\section{Discussion}

The use of Skn-1a ${ }^{-/-}$mice in our physiological recordings and behavioral assays has enabled us to elucidate the function of TRPM5-MCs in the MOE. We found that the EOG responses evoked by odorants and pheromones in Skn-1a ${ }^{-/-}$mice were significantly reduced after 2-wk exposure to a mixture of volatile chemicals at relatively high concentrations and chitin powder compared with water-exposed $\mathrm{Skn}^{-1 \mathrm{a}^{-/-}}$mice. We also found that chemical-exposed Skn-1a $\mathrm{a}^{-/-}$mice were behaviorally compromised in their olfactory-guided food-finding and reactions toward socially and sexually relevant odors. These significant physiologic and behavioral deficits found in Skn- $1 \mathrm{a}^{-1-}$ mice were not observed in control mice treated under the same conditions. Considering that Skn-1a $\mathrm{a}^{-/-}$ mice lack TRPM5-MCs, these results strongly suggest that TRPM5-MCs play an important role in maintaining the olfactory function of the MOE and subsequently ensuring the maintenance of olfactory-guided behaviors under a challenging chemical environment. Therefore, our results reveal a novel mechanism for protective regulation of MOE activity during chemical insult.

The TRPM5-MC-mediated protective regulation we observed in this study can be distinguished from sensory adaption within the OSNs. In sensory adaptation, physiologic responses of OSNs to prolonged odor stimulation are decreased over time via intracellular $\mathrm{Ca}^{2+}$-mediated down-regulation of olfactory signal transduction, active $\mathrm{Ca}^{2+}$ clearance, and decreased expression of cognate odorant receptor genes to the stimulus (Munger et al., 2001; Stephan et al., 2012; von der Weid et al., 2015; Ferguson and Zhao, 2017). Thus, sensory adaptation occurs in specific OSNs that express odorant receptors to the exposed stimulus. However, chemical-exposed Skn$1 \mathrm{a}^{-/-}$mice responded significantly less not only to the chemicals used for chronic exposure, but also to structurally unrelated chemicals and pheromones, suggesting that olfactory sensation is generally compromised. Therefore, it is unlikely that sensory adaptation is the primarily mechanism responsible for the phenotypes observed in our experimental conditions.

What mechanisms are likely to underlie the general compromise in odor responses of Skn- $1 \mathrm{a}^{-/-}$mice during chronic chemical exposure? It is unlikely that tissue damage was a major contributing factor, because similar morphology and cell marker expression were found in the MOE lining the olfactory turbinate of water- and chemicalexposed Skn-1a ${ }^{-/-}$mouse groups. Skn-1a is expressed in the TRPM5-MCs and a minor subset of olfactory progenitor neurons (Yamaguchi et al., 2014). Even if Skn-1a were necessary for the functional differentiation of some OSNs, their population should be very limited. The loss of those
OSNs or their function due to Skn-1a deficiency should not cause such a general olfactory deficit during chemical exposure. This explanation is supported by our data obtained from Skn-1a ${ }^{-/-}$mice housed under our standard conditions, which did not show deficits in EOG responses to the set of odorants and pheromones tested. Rather, the loss of TRPM5-MCs can account for the compromised odor responses of Skn-1 $\mathrm{a}^{-/-}$mice during chemical exposure. As reported by Ogura et al. (2011), TRPM5-MCs can be activated by a variety of chemicals including odorants at high concentrations, ATP, and bacterial substances. TRPM5-MCs are also capable of synthesis and release of $\mathrm{ACh}$, which potently increases intracellular $\mathrm{Ca}^{2+}$ levels in neighboring SCs and suppresses $\mathrm{Ca}^{2+}$ increases induced by the adenylyl cyclase activator forskolin in some OSNs due to differential expression of muscarinic ACh receptor (AChR) subtypes. Cholinergic enhancement of olfactory responses via M3 AChR-mediated modulation of odor receptor activation was recently reported by another group (Jiang et al., 2015). Therefore, cholinergic pathways in the MOE play an important role in modulating olfactory activity under various chemical environments.

Cholinergic paracrine regulation mediated by nonneuronal cell types within the MOE has not been investigated until now. TRPM5-MCs are responsive to odorous stimuli at the level of $500 \mu \mathrm{M}$ and higher, with little sensitivity to odorants at low concentrations that are sufficient to stimulate OSNs (Ogura et al., 2011). Based on this fact and the phenotypes we observed in chemical-exposed Skn-1a ${ }^{-/-}$ mice, we speculate that cholinergic TRPM5-MC-mediated regulation is more tuned to functional maintenance when the MOE is challenged by high levels of chemical stimuli. This explanation is also supported by our results showing comparable EOG and behavior between control and Skn-1 $1 \mathrm{a}^{-/-}$mice under standard housing conditions. OSNs reportedly express M2 and M4 AChRs (Ogura et al., 2011). Activation of these inhibitory receptors leads to a decrease in the cAMP production via Gai/o pathway (Felder, 1995), which in OSNs would reduce potential damage from $\mathrm{Ca}^{2+}$ overload caused by nonspecific stimulation by high levels of odorants. This intercellular mechanism is expected to affect the MOE activity broadly during chemical exposure and would not be limited to the specific OSNs that are especially sensitive to the exposure odorants.

The results obtained from our behavioral studies are in strong agreement with our physiologic findings. All three assays showed that the olfactory-guided behaviors of food searching and preferential reactions toward social and sexual odors are impaired in chemical-exposed Skn$1 \mathrm{a}^{-/-}$mice. These significant behavioral impairments were not observed in chemical-exposed control mice. Because 
A

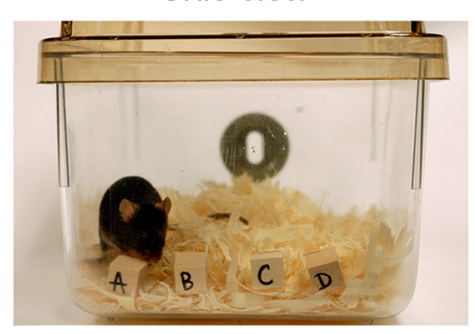

B

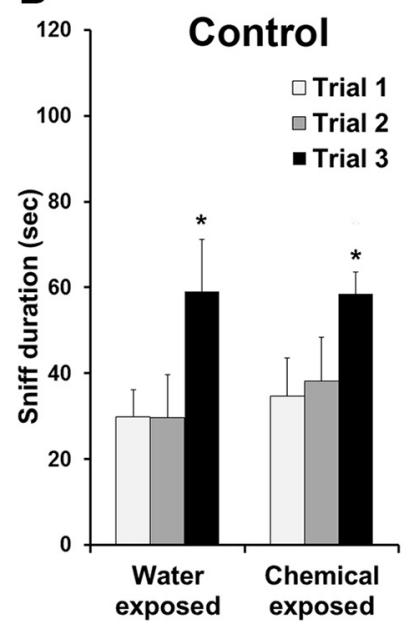

D

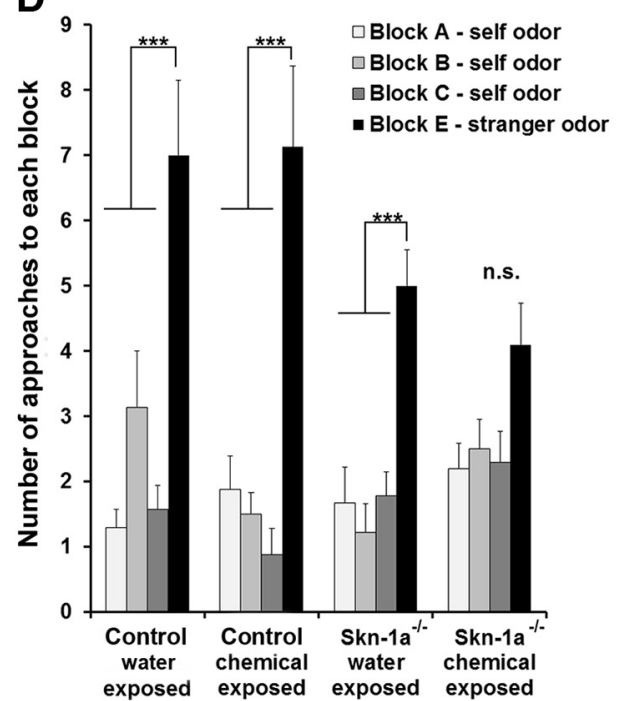

Top view

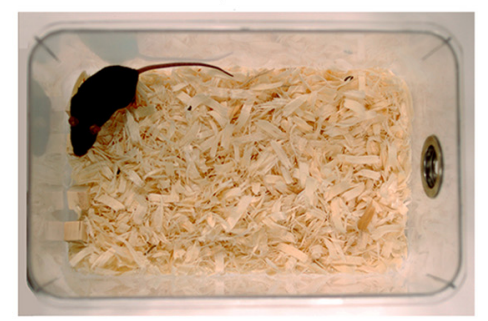

C

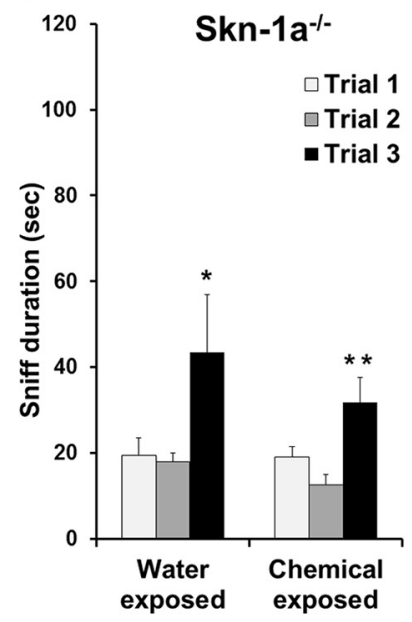

E

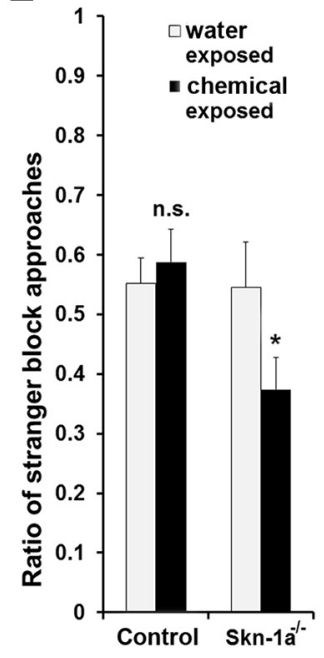

Figure 6. The number of approaches to a novel social odor is reduced in Skn-1a ${ }^{-/-}$mice after chemical exposure. $\boldsymbol{A}$, Photographs of the experimental setting for the block test. Four scented blocks were placed into the cage. Left panel: side view, a mouse was sniffing block A. Right panel: top view. B, Sniff duration for each trial in water- and chemical-exposed groups of control mice. There were three trials total with each lasting $120 \mathrm{~s}$. All blocks in trials 1 and 2 were scented with the mouse's own odors. In trial 3 , the block D was replaced with a block scented with a stranger odor (block E). Control mice of both water- and chemical-exposed groups sniffed significantly longer in trial $3(*, p<0.05$, trial 3 vs. trial $2, t$ test, $n=7-8)$. C, Sniff duration for each trial in water- and chemical-exposed groups of Skn-1 $\mathrm{a}^{-/-}$mice. Skn-1 $\mathrm{a}^{-/-}$mice in both conditions displayed significantly longer sniff duration in trial $3(*$, $p<0.05$, **, $p<0.01$, trial 3 vs. trial $2, t$ test, $n=9-10)$. $\boldsymbol{D}$, Number of approaches to each block during trial 3 in water- or chemical-exposed groups of control and Skn-1 $\mathrm{a}^{-/-}$mice. In control mice, both water- and chemical-exposed groups approached the block scented with a stranger odor significantly more than the three blocks scented with the mouse's own odors $(* * *, p<0.0001$, one-way ANOVA, $n=7$ and 8). Similarly, water-exposed Skn-1a ${ }^{-/-}$mice also approached the stranger odor block significantly more ( $* * *, p<0.0001$, one-way ANOVA, $n=9$ ). However, chemical-exposed Skn-1 $\mathrm{a}^{-/-}$mice failed to show significantly more approaches to the stranger scented block compared with other blocks scented with their own odors, although the number trends higher [one-way 
continued

ANOVA $(p=0.0341)$, Bonferroni corrections vs. the stranger scent block $(P s>0.05)]$. $\boldsymbol{E}$, Comparison of preference index. The index was calculated using the number of approaches to the stranger scented block versus the number of approaches to all blocks. Although the preference index is very similar between the water- and chemical-exposed groups of control mice, the ratio of chemical-exposed Skn-1a ${ }^{-/-}$mice was significantly lower than the ratio of water-exposed Skn-1a ${ }^{-/-}$mice $(*, p<0.05, t$ test, $n=9$ and 10).

we also observed a significant reduction in evoked EOG responses to odorants and pheromones in chemicalexposed Skn-1 $\mathrm{a}^{-/-}$mice, we consider that these behavioral impairments result directly from their impaired MOE function. Recently, TRPM5 was reported to express in a small population of vomeronasal sensory neurons (VSNs; Kusumakshi et al., 2015). The function of these VSNs and whether they require Skn-1a for functional differentiation have not been determined. In our block test, chemicalexposed Skn-1 $\mathrm{a}^{-/-}$mice still spent significantly more time sniffing the novel block than the familiar blocks scented by their own odors. The sniffing duration may reflect chemical sensing by both the main and accessory olfactory systems, because both systems process semiochemical information in parallel, also implying that the VNO function is intact in Skn-1 $\mathrm{a}^{-/-}$mice. However, sensory detection via the $\mathrm{VNO}$ requires animals to contact the stimulus source closely so that nonvolatile semiochemicals can be taken into the VNO (Halpern and MartinezMarcos, 2003; Luo et al., 2003). Because VSNs are not the primary neurons guiding the cognitive behavior that relies on olfactory cues (and active approaching requires chemical detection in the MOE; Keller et al., 2006; Slotnick et al., 2010), the significant reduction in the number of approaches to the stranger-scented block is evidence of impaired olfactory function of the MOE. In Skn- $1 a^{-/-}$mice, TRPM5-expressing taste receptor cells in the tongue and solitary chemosensory cells in the gut and respiratory passageway are also eliminated (Matsumoto et al., 2011; Ohmoto et al., 2013; Gerbe et al., 2016). It remains to be determined whether the lack of TRPM5-expressing cells in other tissues would adversely impact olfactory-guided behaviors.

In both the natural environment and occupational settings, humans and animals are exposed to a wide range of chemicals either sporadically or chronically in countless combinations and conditions. Chronic and severe chemical exposure is known to induce rhinitis, olfactory dysfunction, and other respiratory illnesses (Doty and Mishra, 2001; Kerr, 2015), which may be because such conditions likely overpower the ability of TRPM5-MCs to maintain MOE function. Therefore, our intention for this study was to choose chemical exposure conditions, to the best of our knowledge, that would challenge but not overwhelm the MOE's ability to maintain its integrity so that we could evaluate the role of TRPM5-MCs in epithelial maintenance. Our chosen chemical exposure conditions produced no obvious tissue damage in the MOE of olfactory turbinates (Fig. 3) and had only a minor effect on the olfactory function of control mice (Fig. 2). Because of the limited knowledge about these cells and the MOE chemical defense mechanisms, our conditions for chemical exposure might not be the optimal way to engage
TRPM5-MCs. Also, in our physiologic recordings, we used individual odorants and pheromones to evoke EOG responses, whereas in our behavioral assays, complex olfactory cues from food odor, urine samples, and body scents guided the mouse behavior. Because we used mice of both sexes in our physiologic study, we chose to stimulate the MOE with synthetic urinary pheromones instead of diluted urine samples, which include hundreds of volatiles, semiochemicals, and ions at various concentrations (Schaefer et al., 2002). This strategy allowed us to avoid complications caused by sex-specific variations in urinary components and responses, thus reducing the number of mice used for this study. Future studies may need to evaluate the physiologic impact of chemical exposure and Skn-1a knockout on olfactory responses to complex odor blends. Despite the limitations, our results have uncovered a novel intercellular mechanism for maintaining MOE function. Additionally, our results provide new knowledge about the diverse and important roles of TRPM5-expressing chemosensory cells found in the respiratory, gastrointestinal, urinary tracts, etc. (Lin et al., 2008a; Ogura et al., 2010; Tizzano et al., 2010; Finger and Kinnamon, 2011; Krasteva et al., 2011; Deckmann et al., 2014; Gerbe et al., 2016; Howitt et al., 2016). Our current findings about the function of TRPM5-MCs are consistent with the overall physiologic functions of these TRPM5expressing chemosensory cells.

In conclusion, we have identified novel TRPM5-MCmediated protective regulation that enables the MOE to sustain its function in a relatively strong chemical environment without compromising olfactory-guided behaviors.

\section{References}

Achiraman S, Archunan G (2002) Urinary proteins and pheromonal communication in mammals. Indian J Exp Biol 40:1077-1078. Medline

Bezencon C, Furholz A, Raymond F, Mansourian R, Metairon S, Le Coutre J, Damak S (2008) Murine intestinal cells expressing Trpm5 are mostly brush cells and express markers of neuronal and inflammatory cells. J Comp Neur 509:514-525. CrossRef

Blanchard DC, Griebel G, Pobbe R, Blanchard RJ (2011) Risk assessment as an evolved threat detection and analysis process. Neurosci Biobehav Rev 35:991-998. CrossRef Medline

Boase S, Foreman A, Cleland E, Tan L, Melton-Kreft R, Pant H, Hu FZ, Ehrlich GD, Wormald PJ (2013) The microbiome of chronic rhinosinusitis: culture, molecular diagnostics and biofilm detection. BMC Infect Dis 13:210. CrossRef Medline

Boehm T, Zufall F (2006) MHC peptides and the sensory evaluation of genotype. Trends Neurosci 29:100-107. CrossRef Medline

Brennan PA, Zufall F (2006) Pheromonal communication in vertebrates. Nature 444:308-315. CrossRef Medline

Buck LB (2004) Olfactory receptors and odor coding in mammals. Nutr Rev 62:S184-S188. Medline

Chen Y, Getchell ML, Ding X, Getchell TV (1992) Immunolocalization of two cytochrome P450 isozymes in rat nasal chemosensory tissue. Neuroreport 3:749-752. Medline 
Clapp TR, Medler KF, Damak S, Margolskee RF, Kinnamon SC (2006) Mouse taste cells with G protein-coupled taste receptors lack voltage-gated calcium channels and SNAP-25. BMC Biol 4:7.

Deckmann K, Filipski K, Krasteva-Christ G, Fronius M, Althaus M, Rafiq A, Papadakis T, Renno L, Jurastow I, Wessels L, Wolff M, Schutz B, Weihe E, Chubanov V, Gudermann T, Klein J, Bschleipfer T, Kummer W (2014) Bitter triggers acetylcholine release from polymodal urethral chemosensory cells and bladder reflexes. Proc Natl Acad Sci U S A 111:8287-8292. CrossRef Medline

Doty RL, Mishra A (2001) Olfaction and its alteration by nasal obstruction, rhinitis, and rhinosinusitis. Laryngoscope 111:409-423. CrossRef Medline

Dunston D, Ashby S, Krosnowski K, Ogura T, Lin W (2013) An effective manual deboning method to prepare intact mouse nasal tissue with preserved anatomical organization. J Vis Exp 78. doi: 10.3791/50538.

Elsaesser R, Paysan J (2007) The sense of smell, its signalling pathways, and the dichotomy of cilia and microvilli in olfactory sensory cells. BMC Neurosci 8 (Suppl 3):S1. CrossRef

Farbman A (2000) Cell Biology of Olfactory Epithelium. In: The Neurobiology of Taste and Smell, 2nd ed. (Finger TE, Silver WL, Restrepo D, eds), pp. 131-158. New York: Wiley-Liss.

Felder CC (1995) Muscarinic acetylcholine receptors: signal transduction through multiple effectors. FASEB J 9:619-625. Medline

Ferguson CH, Zhao H (2017) Simultaneous loss of NCKX4 and CNG channel desensitization impairs olfactory sensitivity. J Neurosci 37:110-119. CrossRef

Finger TE, Bottger B, Hansen A, Anderson KT, Alimohammadi $H$, Silver WL (2003) Solitary chemoreceptor cells in the nasal cavity serve as sentinels of respiration. Proc Natl Acad Sci U S A 100: 8981-8986. CrossRef Medline

Finger TE, Kinnamon SC (2011) Taste isn't just for taste buds anymore. F1000 Biol Rep 3:20. CrossRef Medline

Fleming SM, Tetreault NA, Mulligan CK, Hutson CB, Masliah E, Chesselet MF (2008) Olfactory deficits in mice overexpressing human wildtype alpha-synuclein. Eur J Neurosci 28:247-256. CrossRef Medline

Fraser EJ, Shah NM (2014) Complex chemosensory control of female reproductive behaviors. PLoS One 9:e90368. CrossRef Medline

Gerbe F, Sidot E, Smyth DJ, Ohmoto M, Matsumoto I, Dardalhon V, Cesses P, Garnier L, Pouzolles M, Brulin B, Bruschi M, Harcus Y, Zimmermann VS, Taylor N, Maizels RM, Jay P (2016) Intestinal epithelial tuft cells initiate type 2 mucosal immunity to helminth parasites. Nature 529:226-230. CrossRef Medline

Gulbransen BD, Clapp TR, Finger TE, Kinnamon SC (2008) Nasal solitary chemoreceptor cell responses to bitter and trigeminal stimulants in vitro. J Neurophysiol 99:2929-2937. CrossRef Medline

Halpern M, Martinez-Marcos A (2003) Structure and function of the vomeronasal system: an update. Prog Neurobiol 70:245-318. Medline

Hansen A, Finger TE (2008) Is TrpM5 a reliable marker for chemosensory cells? Multiple types of microvillous cells in the main olfactory epithelium of mice. BMC Neurosci 9:115. CrossRef Medline

Hegg CC, Jia C, Chick WS, Restrepo D, Hansen A (2010) Microvillous cells expressing IP3 receptor type 3 in the olfactory epithelium of mice. Eur J Neurosci 32:1632-1645. CrossRef Medline

Howitt MR, Lavoie S, Michaud M, Blum AM, Tran SV, Weinstock JV, Gallini CA, Redding K, Margolskee RF, Osborne LC, Artis D, Garrett WS (2016) Tuft cells, taste-chemosensory cells, orchestrate parasite type 2 immunity in the gut. Science 351:1329-1333. CrossRef Medline

Imamura F, Hasegawa-Ishii S (2016) Environmental toxicantsinduced immune responses in the olfactory mucosa. Front Immunol 7:475. CrossRef Medline

Jia C, Hayoz S, Hutch CR, lqbal TR, Pooley AE, Hegg CC (2013) An IP3R3- and NPY-expressing microvillous cell mediates tissue ho- meostasis and regeneration in the mouse olfactory epithelium. PLoS One 8:e58668. CrossRef Medline

Jiang Y, Li YR, Tian H, Ma M, Matsunami H (2015) Muscarinic acetylcholine receptor $\mathrm{M} 3$ modulates odorant receptor activity via inhibition of beta-arrestin-2 recruitment. Nat Commun 6:6448.

Kavaliers M, Wiebe JP, Galea LA (1994) Male preference for the odors of estrous female mice is enhanced by the neurosteroid 3 alpha-hydroxy-4-pregnen-20-one (3 alpha HP). Brain Res 646: 140-144. Medline

Keller M, Douhard Q, Baum MJ, Bakker J (2006) Destruction of the main olfactory epithelium reduces female sexual behavior and olfactory investigation in female mice. Chem Senses 31:315-323. CrossRef Medline

Kerr KJ (2015) Gulf War illness: an overview of events, most prevalent health outcomes, exposures, and clues as to pathogenesis. Rev Environ Health 30:273-286. CrossRef

Keverne EB (2004) Importance of olfactory and vomeronasal systems for male sexual function. Physiol Behav 83:177-187. CrossRef Medline

Krasteva G, Canning BJ, Hartmann P, Veres TZ, Papadakis T, Muhlfeld C, Schliecker K, Tallini YN, Braun A, Hackstein H, Baal N, Weihe E, Schutz B, Kotlikoff M, Ibanez-Tallon I, Kummer W (2011) Cholinergic chemosensory cells in the trachea regulate breathing. Proc Natl Acad Sci U S A 108:9478-9483. CrossRef Medline

Kusumakshi S, Voigt A, Hübner S, Hermans-Borgmeyer I, Ortalli $A$, Pyrski M, Dörr J, Zufall F, Flockerzi V, Meyerhof W, Montmayeur JP, Boehm U (2015) A binary genetic approach to characterize TRPM5 cells in mice. Chem Senses 6:413-425. CrossRef

Kuwabara Y, Alexeeff GV, Broadwin R, Salmon AG (2007) Evaluation and application of the RD50 for determining acceptable exposure levels of airborne sensory irritants for the general public. Environ Health Perspect 115:1609-1616. CrossRef Medline

Lehmkuhl AM, Dirr ER, Fleming SM (2014) Olfactory assays for mouse models of neurodegenerative disease. J Vis Exp e51804

Lin W, Ezekwe EA, Jr., Zhao Z, Liman ER, Restrepo D (2008b) TRPM5-expressing microvillous cells in the main olfactory epithelium. BMC Neurosci 9:114. CrossRef Medline

Lin W, Margolskee R, Donnert G, Hell SW, Restrepo D (2007) Olfactory neurons expressing transient receptor potential channel M5 (TRPM5) are involved in sensing semiochemicals. Proc Natl Acad Sci U S A 104:2471-2476. CrossRef Medline

Lin W, Ogura T, Margolskee RF, Finger TE, Restrepo D (2008a) TRPM5-expressing solitary chemosensory cells respond to odorous irritants. J Neurophysiol 99:1451-1460. CrossRef Medline

Lopez F, Delgado R, Lopez R, Bacigalupo J, Restrepo D (2014) Transduction for pheromones in the main olfactory epithelium is mediated by the Ca2+-activated channel TRPM5. J Neurosci 34:3268-3278. CrossRef Medline

Luo M, Fee MS, Katz LC (2003) Encoding pheromonal signals in the accessory olfactory bulb of behaving mice. Science 299:11961201. CrossRef Medline

Mandiyan VS, Coats JK, Shah NM (2005) Deficits in sexual and aggressive behaviors in Cnga2 mutant mice. Nat Neurosci 8:1660-1662. CrossRef Medline

Matsumoto I, Ohmoto M, Narukawa M, Yoshihara Y, Abe K (2011) Skn-1a (Pou2f3) specifies taste receptor cell lineage. Nat Neurosci 14:685-687. CrossRef Medline

Menco BP, Morrison EE (2003) Morphology of the Mammalian OIfactory Epithelium: Form, Fine Structure, Function, and Pathology. In: Handbook of Olfaction and Gustation, 2nd ed. (Doty RL, ed), pp 17-50. New York: Marcel Dekker, Inc.

Morrison EE, Costanzo RM (1992) Morphology of olfactory epithelium in humans and other vertebrates. Microsc Res Tech 23:4961. CrossRef Medline

Munger SD, Lane AP, Zhong H, Leinders-Zufall T, Yau KW, Zufall F, Reed RR (2001) Central role of the CNGA4 channel subunit in Ca2+-calmodulin-dependent odor adaptation. Science 294:21722175. CrossRef Medline

Ogura T, Krosnowski K, Zhang L, Bekkerman M, Lin W (2010) Chemoreception regulates chemical access to mouse vomerona- 
sal organ: role of solitary chemosensory cells. PLoS One 5:e11924. CrossRef Medline

Ogura T, Szebenyi SA, Krosnowski K, Sathyanesan A, Jackson J, Lin W (2011) Cholinergic microvillous cells in the mouse main olfactory epithelium and effect of acetylcholine on olfactory sensory neurons and supporting cells. J Neurophysiol 106:1274-1287. CrossRef

Ohmoto M, Yamaguchi T, Yamashita J, Bachmanov AA, Hirota J, Matsumoto I (2013) Pou2f3/Skn-1a is necessary for the generation or differentiation of solitary chemosensory cells in the anterior nasal cavity. Biosci Biotechnol Biochem 77:2154-2156. CrossRef Medline

Peretto P, Paredes RG (2014) Social Cues, Adult Neurogenesis, and Reproductive Behavior. In: Neurobiology of Chemical Communication, 2014/05/16 Edition (Mucignat-Caretta C, ed), Boca Raton, FL: CRC Press.

Prediger RD, Batista LC, Medeiros R, Pandolfo P, Florio JC, Takahashi RN (2006) The risk is in the air: Intranasal administration of MPTP to rats reproducing clinical features of Parkinson's disease. Exp Neurol 202:391-403. CrossRef Medline

Restrepo D, Arellano J, Oliva AM, Schaefer ML, Lin W (2004) Emerging views on the distinct but related roles of the main and accessory olfactory systems in responsiveness to chemosensory signals in mice. Horm Behav 46:247-256. CrossRef Medline

Restrepo D, Lin W, Salcedo E, Yamazaki K, Beauchamp G (2006) Odortypes and MHC peptides: complementary chemosignals of MHC haplotype? Trends Neurosci 29:604-609. CrossRef Medline

Schaefer ML, Yamazaki K, Osada K, Restrepo D, Beauchamp GK (2002) Olfactory fingerprints for major histocompatibility complexdetermined body odors II: relationship among odor maps, genetics, odor composition, and behavior. J Neurosci 22:9513-9521.

Slotnick B, Restrepo D, Schellinck H, Archbold G, Price S, Lin W (2010) Accessory olfactory bulb function is modulated by input from the main olfactory epithelium. Eur J Neurosci 31:1108-1116. CrossRef Medline

Stephan AB, Tobochnik S, Dibattista M, Wall CM, Reisert J, Zhao H (2012) The $\mathrm{Na}(+) / \mathrm{Ca}(2+)$ exchanger NCKX4 governs termination and adaptation of the mammalian olfactory response. Nat Neurosci 15:131-137. CrossRef Medline

Thiebaud N, Sigoillot M, Chevalier J, Artur Y, Heydel JM, Le Bon AM (2010) Effects of typical inducers on olfactory xenobioticmetabolizing enzyme, transporter, and transcription factor expression in rats. Drug Metab Dispos 38:1865-1875. CrossRef Medline
Thornton-Manning JR, Nikula KJ, Hotchkiss JA, Avila KJ, Rohrbacher KD, Ding X, Dahl AR (1997) Nasal cytochrome P450 2A: identification, regional localization, and metabolic activity toward hexamethylphosphoramide, a known nasal carcinogen. Toxicol Appl Pharmacol 142:22-30. CrossRef Medline

Tillerson JL, Caudle WM, Parent JM, Gong C, Schallert T, Miller GW (2006) Olfactory discrimination deficits in mice lacking the dopamine transporter or the D2 dopamine receptor. Behav Brain Res 172:97-105. CrossRef Medline

Tirindelli R, Dibattista M, Pifferi S, Menini A (2009) From pheromones to behavior. Physiol Rev 89:921-956. CrossRef Medline

Tizzano M, Cristofoletti M, Sbarbati A, Finger TE (2011) Expression of taste receptors in solitary chemosensory cells of rodent airways. BMC Pulm Med 11:3. CrossRef Medline

Tizzano M, Gulbransen BD, Vandenbeuch A, Clapp TR, Herman JP, Sibhatu HM, Churchill ME, Silver WL, Kinnamon SC, Finger TE (2010) Nasal chemosensory cells use bitter taste signaling to detect irritants and bacterial signals. Proc Natl Acad Sci U S A 107:3210-3215. CrossRef Medline

Ushiama S, Ishimaru Y, Narukawa M, Yoshioka M, Kozuka C, Watanabe N, Tsunoda M, Osakabe N, Asakura T, Masuzaki H, Abe K (2016) Catecholamines facilitate fuel expenditure and protect against obesity via a novel network of the gut-brain axis in transcription factor Skn-1-deficient mice. EBioMedicine 8:60-71. CrossRef

van Thriel C, Kiesswetter E, Schaper M, Juran SA, Blaszkewicz M, Kleinbeck S (2008) Odor annoyance of environmental chemicals: sensory and cognitive influences. J Toxicol Environ Health A 71: 776-785. CrossRef Medline

von der Weid B, Rossier D, Lindup M, Tuberosa J, Widmer A, Col JD, Kan C, Carleton A, Rodriguez I (2015) Large-scale transcriptional profiling of chemosensory neurons identifies receptor-ligand pairs in vivo. Nat Neurosci 10:1455-1463. CrossRef

Wersinger SR, Caldwell HK, Martinez L, Gold P, Hu SB, Young WS 3rd (2007) Vasopressin 1a receptor knockout mice have a subtle olfactory deficit but normal aggression. Genes Brain Behav 6:540551. CrossRef

Yamaguchi T, Yamashita J, Ohmoto M, Aoude I, Ogura T, Luo W, Bachmanov AA, Lin W, Matsumoto I, Hirota J (2014) Skn-1a/ Pou2f3 is required for the generation of Trpm5-expressing microvillous cells in the mouse main olfactory epithelium. BMC Neurosci 15:13. CrossRef Medline

Yang M, Crawley JN (2009) Simple behavioral assessment of mouse olfaction. Curr Protoc Neurosci Chapter 8:Unit 8.24. 